\title{
The LeATL6-Associated Ubiquitin/Proteasome System May Contribute to Fungal Elicitor-Activated Defense Response via the Jasmonic Acid-Dependent Signaling Pathway in Tomato
}

\author{
Daisuke Hondo, ${ }^{1}$ Shu Hase, ${ }^{1}$ Yoshinori Kanayama, ${ }^{2}$ Nobuyuki Yoshikawa, ${ }^{3}$ Shigehito Takenaka, ${ }^{4}$ and \\ Hideki Takahashi' \\ ${ }^{1}$ Department of Life Science, and ${ }^{2}$ Department of Biological Resource Sciences, Graduate School of Agricultural Science, \\ Tohoku University, Sendai 981-8555, Japan; ${ }^{3}$ Faculty of Agriculture, Iwate University, Morioka 020-8550, Japan; \\ ${ }^{4}$ Department of Upland Agriculture, National Agricultural Research Center for Hokkaido Region, Hokkaido 082-0071, Japan
}

Submitted 15 May 2006. Accepted 18 July 2006.

\begin{abstract}
The expression of LeATL6, an ortholog of Arabidopsis ATL6 that encodes a RING-H2 finger protein, was induced in tomato roots treated with a cell wall protein fraction (CWP) elicitor of the biocontrol agent Pythium oligandrum. The LeATL6 protein was expressed as a fusion protein with a maltose-binding protein (MBP) in Escherichia coli, and it catalyzed the transfer of ubiquitin to the MBP moiety on incubation with ubiquitin, the ubiquitin-activating enzyme E1, and the ubiquitin-conjugating enzyme E2; this indicated that LeATL6 represents ubiquitin ligase E3. LeATL6 expression also was induced by elicitor treatment of jail-1 mutant tomato cells in which the jasmonic acid (JA)-mediated signaling pathway was impaired; however, JA-dependent expression of the basic PR-6 and TPI-1 genes that encode proteinase inhibitor II and I, respectively, was not induced in elicitor-treated jail-1 mutants. Furthermore, transient overexpression of LeATL6 under the control of the Cauliflower mosaic virus $35 \mathrm{~S}$ promoter induced the basic PR6 and TPI-1 expression in wild tomato but not in the jail-1 mutant. In contrast, LeATL6 overexpression did not activate salicylic acid-responsive acidic $P R-1$ and $P R-2$ promoters in wild tomato. These results indicated that elicitor-responsive $L E A T L 6$ probably regulates JA-dependent basic PR6 and TPI-1 gene expression in tomato. The LeATL6-associated ubiquitin/proteasome system may contribute to elicitor-activated defense responses via a JA-dependent signaling pathway in plants.
\end{abstract}

Additional keywords: ATL gene family, induced resistance, Micro-Tom.

Protein degradation in various biological processes such as transcription, signal transduction, and peroxisome biogenesis often is mediated by the ubiquitination pathway (Saurin et al. 1996). In addition, ubiquitin-mediated proteolysis also has been implicated in plant-signaling pathways for responses to phytohormones, photomorphogenesis, sucrose, and pathogens (Devoto et al. 2003; Ellis et al. 2002). Proteolysis of the target protein by the ubiquitination pathway involves three steps: the activation of ubiquitin via the formation of a thioester bond between the target protein and a cysteine at the active site of a

Corresponding author: H. Takahashi, E-mail: takahash@bios.tohoku.ac.jp ubiquitin-activating enzyme (E1), the transfer of the activated ubiquitin to a ubiquitin-conjugated enzyme (E2), and the recognition of the target protein as a substrate by a ubiquitin-protein ligase (E3) (Hershko and Ciechanover 1998; Smalle and Viertra 2004). The ubiquitinated protein is rapidly degraded via the $26 \mathrm{~S}$ proteasome. In the sequential reaction of the three enzymes in the ubiquitination pathway, E3 plays a central role in the recognition of the target protein for ubiquitination.

In plants, E3 ubiquitin ligases are classified into various groups based on the presence of really interesting new genes (RING), HECT, or U-box domains (Vierstra 2003). The RING zinc-finger domain is described as a new class of zinc-finger proteins and is a major part of the E3 ubiquitin ligases (Borden and Freemont 1996; Saurin et al. 1996). The RING zinc-finger domain proteins function in hormone, light, and developmental processes; several target proteins for these processes, including COP1, SINAT5, and RMA1, have been identified (Vierstra 2003). SKP CDC53p/CUL1 F-box (SCF) complexes belong to a family of RING-type E3 ubiquitin ligases (Weissman 2001). The suppressor of G2 allele of SKP1 (SGT1), which was identified as essential defense signaling component, interacts with the required for Mla resistance $1(R A R I)$ and regulates the activity of the SCF complex. SGTI and RARI are required for the resistance $(R)$-gene-mediated resistance to pathogens in plants; therefore, SCF-mediated ubiquitination seems to be an important regulator of the $R$-gene-mediated resistance (Austin et al. 2002; Azevedo et al. 2002; Liu et al. 2002; Muskett et al. 2002; Peart et al. 2002; Shirasu et al. 1999; Tor et al. 2002; Toreno et al. 2002). Subsequent studies using various plant-pathogen combinations provide accumulating evidence indicating the important role played by the ubiquitin/proteaseome system in the defense responses against pathogens. Recently, it has been demonstrated that the RIN2/RIN3 RING E3 ligases, which interact with the $R P M 1$-encoding coiled coil-nucleotide binding site-leucine-rich repeat (LRR)-type $\mathrm{R}$ protein, act on a substrate that regulates $R P M 1$ - and RPS2-dependent hypersensitive response (HR) to Pseudomonas syringae carrying avrRpml or avrRpt2 (Kawasaki et al. 2005). In the $C f$-9- and $C f$-4-dependent HR in tomato and tobacco, it has been demonstrated that $A v r 9 / C f-9$ rapidly elicited $(A C R E)$ genes that encode U-box E3 ubiquitin ligases are essential for defense responses (Durrant et al. 2000; GonzalezLamothe et al. 2006; Yang et al. 2006).

$A T L$ also belongs to a RING zinc-finger gene family in Arabidopsis thaliana, and it contains an amino-terminal transmem- 
brane domain followed by a short basic region and a 16amino-acid residues-conserved region, except for a highly conserved RING-H2 zinc-finger domain (Salinas-Mondragon et al. 1999). Among the members of the ATL gene family, the ATL2 and ATL6 genes are rapidly induced after treatment with a chitin elicitor (Salinas-Mondragon et al. 1999). In addition, it has been demonstrated that, in rice, the expression of an ortholog of the ATL gene family, namely, the elicitor-responsive 5 (EL5) gene, also is upregulated at the early stage of elicitor treatment (Durrant et al. 2000; Takai et al. 2002). However, the function of elicitor-responsive ATL in the activation of defense responses has not been well established thus far.

Essential pathogen components such as cell wall fragments, enzymes, and secreted peptides exhibit defense response-inducible general elicitor activity; these components have been recognized as invariant pathogen-derived determinants called pathogen-associated molecular patterns (PAMPs) (Hammond-Kosack and Parker 2003; Nürnberger et al. 2004). Elicitins are wellstudied sterol-binding proteins and are common PAMPs produced by many Phytophthora and Pythium spp. (Kamoun et al. 1997; Panabieres et al. 1997; Tyler 2002). Multiple sequence alignments and phylogenetic analyses of elicitins and elicitinlike proteins suggest the presence of at least five distinct classes within the elicitin family (Kamoun et al. 1997). Oligandrin is an elicitin-like protein with a molecular mass of approximately 10 $\mathrm{kDa}$ and is secreted by the nonpathogenic organism Pythium oligandrum (Picard et al. 2000). A conclusive study of oligandrininduced resistance against Phytophthora parasitica in tomato has suggested that oligandrin triggers cytological and biochemical modifications in tomato cells, thereby inducing resistance to P. parasitica (Picard et al. 2000). In addition to oligandrin, Takenaka and Kawasaki (1994) have reported glycoprotein elicitor in the cell wall protein fraction (CWP) of Pythium oligandrum. CWP possesses two major proteins, POD-1 and POD-2, that have molecular masses of approximately 28 and $24 \mathrm{kDa}$, respectively. The amino acid sequences deduced from the corresponding cDNA sequences of $P O D-1$ and $P O D-2$ (DDBJ accession numbers AB217820 and AB217821) suggest that these proteins contain O-linked glycosylation sites and elicitin signatures that are the conserved motif of elicitin and elicitin-like proteins of Phytophthora and Pythium spp. listed in the BLOCK motif database (Picard et al. 2000; Ponchet et al. 1999; Takenaka et al. 2006). The purified CWP and mycelial homogenate of $P$. oligandrum that contained CWP induced defense reactions against pathogens in sugar beet and wheat (Takenaka et al. 2003). Furthermore, purified POD-1 and POD-2 each were sufficient to induce resistance to sugar beet seedling disease caused by Aphanomyces cochlioides and expression of several defense-related genes, indicating that POD-1 and POD-2, and also CWP containing them, appeared to have elicitor activity (Takenaka et al. 2006). However, the molecular mechanism underlying recognition of plants to CWP and the downstream signaling pathway for induction of the defense-related gene expression remain to be elucidated.

A global analysis of gene expression in tomato roots treated with CWP by using 11,520 nonredundant cDNA arrays indicated that the expression of approximately 250 genes was altered in the CWP-treated tomato roots (Takahashi et al. in press). Of upregulated 144 genes, defense-related genes (e.g., the basic pathogenesis-related $[\mathrm{PR}]$ protein $[P R-6]$ that encodes proteinase inhibitor II and basic $P R-2$ that encodes $\beta-1,3$-glucanase, which generally are regulated by jasmonic acid [JA]- and ethylene-mediated signaling pathways) were included. Other JA- and ethylene-related genes also were included in the upregulated genes in the CWP-treated tomato roots. The expression of genes that encode an ethylene receptor homolog; an ethylene-responsive transcription factor; an alleneoxide synthase, and a lipoxigenase for JA biosynthesis; and three JA-inducible transcription factors (i.e., JERF1, NAC transcription factor JA2, and MYC transcription factor JA3) clearly were induced in CWPtreated tomato roots. This indicated that JA- and ethylene-dependent signaling pathways appeared to be activated in the CWP-treated tomato roots (Takahashi et al. 2006). However, the expression of acidic $P R$ genes, which generally is regulated via a salicylic acid (SA)-dependent signaling pathway, was not observed in the CWP-treated tomato roots.

While analyzing the putative function of these upregulated gene products in CWP-treated roots, we observed that the expression of one gene encoding the RING-H2 protein was highly induced in tomato roots due to CWP treatment. This gene has been characterized in the present study. Comparative analysis of the amino acid sequences of the RING-H2 protein with other RING-finger proteins and the measurement of the ubiquitin ligase activity of the RING-H2 protein indicated that this protein may be an ortholog of ATL6, a ubiquitin ligase (E3) of Arabidopsis thaliana. Furthermore, the transient overexpression of this RING-H2 gene (LeATL6) in leaves of wild tomato and the jail-1 mutant tomato suggested that the upregulation of LeATL6 may induce JA-dependent defense-related gene expression in CWP-treated tomato.

\section{RESULTS}

\section{Upregulation of LeATL6 in tomato roots treated} with CWP or mycelial homogenate of P. oligandrum.

When tomato roots were treated with CWP, accumulation of the LeATL6 transcript was observed $4 \mathrm{~h}$ after treatment (Fig. 1A). This upregulation of LeATL6 appeared to be a transient

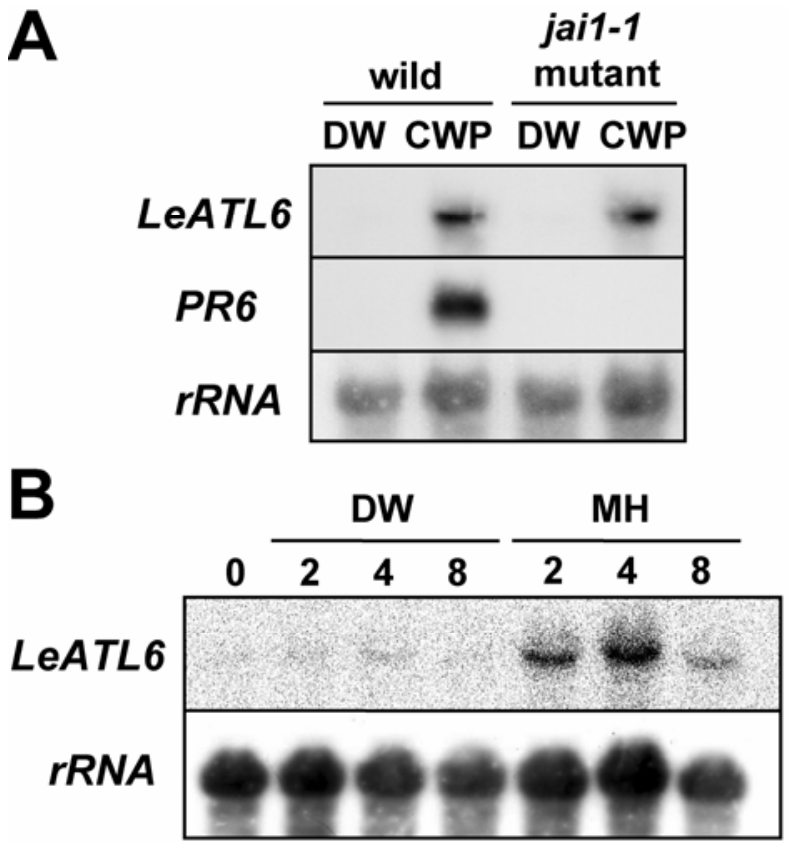

Fig. 1. LeATL6 expression in tomato roots treated with cell wall protein fraction (CWP) or the mycelial homogenate of Pythium oligandrum. A, Northern blot analysis of LeATL6 and PR6 expression in the roots of Lycopersicon esculentum cv. Micro-Tom and its jail-1 mutant treated with the CWP of $P$. oligandrum (CWP) and distilled water (DW) at $4 \mathrm{~h}$ after treatment. The expression of jasmonic acid (JA)-inducible PR6 was analyzed to confirm the phenotype of the jail-1 mutant in which the JA-dependent signaling pathway was impaired. rRNA was detected as the internal RNA control. B, Time course of LeATL6 expression in the roots of L. esculentum cv. Micro-Tom treated with the mycelial homogenate of $P$. oligandrum by Northern blot analysis. The transcript of LeATL6 and rRNA as an internal control were analyzed $0,2,4$, and $8 \mathrm{~h}$ after treatment with the mycelial homogenate containing CWP $(\mathrm{MH})$ or DW. 
response to CWP; this was because the induction of LeATL6 expression was detected $2 \mathrm{~h}$ after treatment with the mycelial homogenate of $P$. oligandrum containing CWP, and then it gradually started decreasing $8 \mathrm{~h}$ after treatment (Fig. 1B). LeATL6 expression also was induced in the CWP-treated jail1 mutant tomato roots in which the JA-dependent signaling pathway was impaired. On the other hand, the expression of JA-inducible basic PR6 encoding proteinase inhibitor II was not induced in jail-1 by CWP treatment (Fig. 1A). Therefore, we believe that LeATL6 expression appears to be induced by CWP in tomato roots via a JA-independent signaling pathway or that LeATL6 functions upstream of JAII-1 in the JA-dependent signaling pathway, which is activated by CWP.

\section{Comparison of the amino acid sequences of LeATL6 with other RING-H2 finger domain genes from plants.}

The cDNA of LeATL6 was cloned from the total RNA purified from CWP-treated tomato roots. The amino acid sequence deduced from LeATL6 cDNA is shown in Figure 2. It was identical to the deduced amino acid sequence of the tomato expressed sequence tag clone (TIGR LeGI number TC126693) that was exhibited in the TIGR tomato genome database. Comparative analysis of the motif structure of other RING-H2 finger genes suggested that LeATL6 contained a transmembranelike hydrophobic region (region I), basic amino-acid-rich region (region II), a highly conserved amino acid sequence-containing region (region III), and a RING-H2 zinc-finger domain (region IV) flanked by acidic and basic amino acids, which commonly are observed in the ATL family (Fig. 2) (Salinas-Mondragon et al. 1999). Further homology search of the amino acid sequence of LeATL6 with those of the members of the ATL family indicated that LeATL6 has the highest identity with ATL6 of $A$. thaliana (AtATL6). Therefore, we believed LeATL6 to be an ortholog of AtATL6.

\section{Ubiquitin ligase activity of LeATL6.}

As the first step toward analysis of whether LeATL6 plays a functional role in CWP-induced defense responses, the ubiquitin ligase (E3) activity of LeATL6 was measured; this was done because the ATL family proteins function as ubiquitin ligases in the ubiquitin/proteasome system (Serrano et al. 2006). Takai and associates (2002) have reported that they were able to get a sufficient amount of the fusion protein of maltose-binding protein (MBP) and truncated EL5 that excluded the N-terminal transmembrane domain and the basic region by expression it in Escherichia coli. Therefore, to obtain a sufficient amount of active LeATL6, truncated LeATL6 in which the N-terminal 98-amino acid region containing both the transmembrane domain and the basic region was deleted, and was expressed in E. coli as a fusion protein with MBP; the fusion protein was designated as MBP-LeATL6 (Fig. 3A). Abundantly expressed MBP-LeATL6 was present in the soluble protein fraction and was purified by amylose affinity chromatography (Fig. 3A). MBP-LeATL6 was incubated with ubiquitin, ATP, and wheat germ lysate as a source of the ubiquitin-activating enzyme (E1) and the ubiquitin-conjugating enzyme (E2). Aliquots of the reaction mixture

\section{L.esculentum LeATL6 \\ A.thaliana ATL6 \\ A.thaliana ATL2 \\ 0.sativa EL5}

\section{L.esculentum LeATL6 \\ A. thaliana ATL6 \\ A. thaliana ATL2 \\ 0.sativa EL5}

L.esculentum LeATL6

A. thaliana ATL6

A. thaliana ATL2

O.sativa EL5

L.esculentum LeATL6

A. thaliana ATL6

A. thaliana ATL2

0.sativa EL5

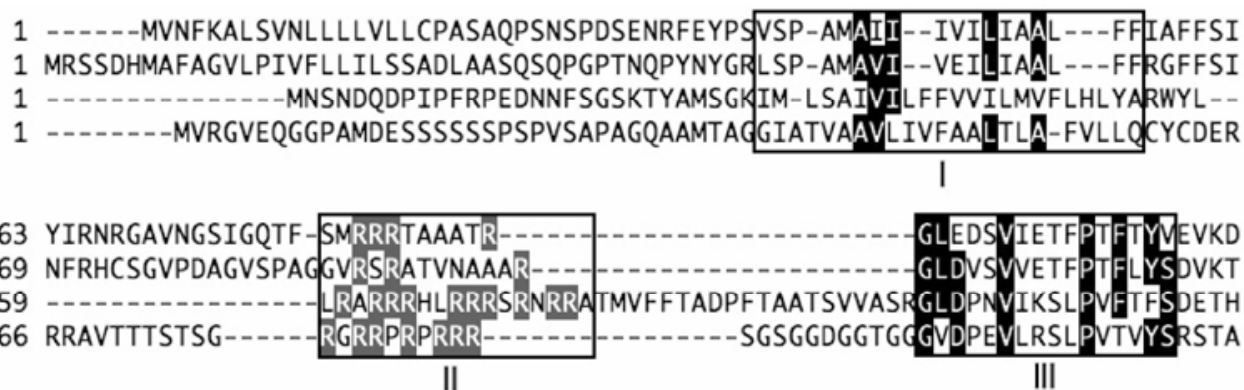

$110 \mathrm{HH}-{ }^{---1 G K G A L E C A V C L N E F E D D E M L R L I P K C D H V F H P E C I D A W L K S H V T C P V C R A D L T P K P D E P V P V Q T ~}$ 119 QK-----LGKGELECAICLNEFEDDETLRLLPKCDHVFHPHCIDANLEAHVTCPVCRANLAEQVAEGESVEP 114 118 AAAAKEEEEEDDDGVECAVCLAELEDGEEARFLPRCGHGFHAECVDMWGSHSTCPLCRLTVVVPPPPLPPVPP IV

177 PEVNRELGQEQENTQQNNEVTIQIDVDENLMSQQEETSVKPEVKRNLSFNAVNRPPRSFSLKRPKMLSKFRSHS 186 GGTEPDLELQQVVVNPEPVVTAPVPEQLVTSEVDSRRLPGVPVDLKRVKFSRSHTTGHSVVQPGECTERFTLRL 177 REREVVIAVDSDPVLVIEPSSSSGLTDEPHGSGSSQMLREDSGRKPAAIEVPRRTFSEFEDELTRRDSPASQSF 192 EPPASYTVSLPASVLLGLSDHGAGAVTMTAEGRSTLVIEIPESAASTTPRDAAARSSPSLARLRSLRRLWSFGR
62

68

58

65

109

118

113

117

176

185

176

191

Fig. 2. Multiple alignment of the amino acid sequences of LeATL6 and other really interesting new gene (RING)-H2 finger proteins. The amino acid sequences deduced from the cDNAs of LeATL6, Arabidopsis ATL2, and ATL6 (GenBank accession numbers L76926 and AF132016, respectively) and rice EL5 (AB045120) were aligned. The transmembrane-like hydrophobic region (I), the basic amino-acid-rich region (II), the highly conserved amino acid sequencerich region (III), and the RING-H2 zinc finger domain (IV), which commonly are observed in the ATL gene family, are indicated with surrounding lines. Basic residues are shown against a gray background in region II. The amino acid residues that are common to regions I, III, and IV are shown against a black background. 
were sampled and subjected to $7.5 \%$ sodium dodecyl sulfate polyacrylamide gel electrophoresis (SDS-PAGE), and MBPLeATL6 then was detected immunologically using the anti-MBP antibody. Modified high molecular weight MBP-LeATL6 bands appeared after incubation of MBP-LeATL6 with the wheat germ lysate, whereas they did not appear in the absence of the wheat germ lysate (Fig. 3B). When MBP alone was incubated with ubiquitin, ATP, and the wheat germ lysate, high molecular weight bands were not observed (Fig. 3B). These results indicated that LeATL6 possessed E3 activity by which it catalyzed the transfer of ubiquitin to the MBP moiety. Although low molecular weight protein bands also were detected by anti-MBP antibody (Fig. 3B), they seemed to be a partial degradation product of full MBP-LeATL6 protein, because similar bands appeared in MBP-LeATL6 fusion protein fraction (Fig. 3A, lane $5 \mathrm{~A})$ purified by amylose affinity chromatography.

\section{Coexpression of CaMV 35S promoter-controlled LeATL6 and JA-dependent $P R 6$ and TPI-1 promoter-controlled DsRed reporter constructs in tomato cells.}

Using particle bombardment, tomato cells were introduced with a combination of 35Spro:LeATL6 and 35Spro:GFP constructs in which LeATL6 and GFP were under the control of the Cauliflower mosaic virus (CaMV) 35S promoter, respectively, or a single 35Spro:GFP construct as a control with or without the PR6pro:DsRed construct in which the DsRed reporter was under the control of the JA-responsive basic PR6 promoter. Initially, construct-introduced cells were identified by detecting GFP fluorescence followed by DsRed fluorescence caused by the activation of the PR6 promoter in these cells (Fig. 4A and B). In the cells expressing GFP, approximately $10 \%$ of the cells exhibited DsRed expression without the 35Spro:LeATL6 construct (Fig. 5), whereas GFP fluorescence was noticeably detected in all cells expressing DsRed (data not shown).

When LeATL6 was transiently overexpressed under the control of the CaMV 35S promoter in tomato cells, DsRed expression under the control of the PR6 promoter was induced (Fig. 4A). The DsRed signal was observed in 31 of 60 cells that expressed GFP (Fig. 5A). However, when PR6pro:DsRed and 35Spro:GFP constructs were coexpressed in tomato cells, a weak DsRed signal was observed in only 13 of the 60 cells that expressed GFP (Fig. 5A). This GFP signal also was observed at the emission range for the detection of the DsRed signal because this range enables the detection of the GFP signal (Fig. 4). This significant increase in the number of DsRed-expressing cells by the coexpression of LeATL6 suggested that PR6pro:DsRed expression depended on the overexpression of LeATL6 but was independent of GFP expression. The DsRed signal was not observed in any of the cells introduced with only a combination of the 35Spro:LeATL6 and 35Spro:GFP constructs or with the single 35Spro:GFP construct (Fig. 4A). When 35Spro:LeATL6 was coexpressed with the NtPR2pro:DsRed construct in which DsRed expression is under the control of the SA-responsive acidic $P R 2$ promoter, a weak DsRed signal was observed in only 13 of the 60 cells that expressed GFP. This implied that the acidic PR2 promoter was not activated by the overexpression of LeATL6 (Figs. 4A and 5A).

To further confirm the activation of basic defense-related gene expression by overexpression of LeATL6, expression of a second set of defense-related genes, basic proteinase inhibitor I (TPI-1) and acidic $P R-1$ genes, was examined with or without 35Spro:LeATL6 construct. When TPI-1pro:DsRed was coexpressed with the 35Spro:LeATL6 construct, the DsRed signal was observed in 28 of 60 cells that expressed GFP (Figs. $4 \mathrm{C}$ and 5B). However, when the NtPRlpro:DsRed was coexpressed with the 35Spro:LeATL6 construct, a weak DsRed signal was observed in only 14 of the 60 cells that expressed GFP.
These results indicated that LeATL6 overexpression activated the basic PR6 and TPI- 1 promoters but not the acidic $P R 2$ and $P R 1$ promoters in wild tomato cells.

When a combination of the 35Spro:LeATL6 and 35Spro:GFP constructs was introduced into jail-1 mutant tomato cells with the PR6pro:DsRed construct, the DsRed fluorescence signal was observed in only approximately 10 of the 60 DsRed-expressing cells of the jail-1 mutant as well as in the jail-1 mutant tomato cells introduced with the 35Spro:GFP and PR6pro:DsRed constructs (Figs. 4B and 5A). The expression of TPI-1pro:DsRed by overexpression of 35Spro:LeATL6 also was cancelled in the jail-1 (Figs. 4D and 5B). These results indicated that the activation of the basic PR6 and TPI-1 promoters by LeATL6 overexpression probably is induced in a JAI1-1-dependent manner.

\section{DISCUSSION}

Arabidopsis spp. have approximately 470 genes that encode RING zinc-finger domain proteins. The ATL gene family that encodes putative RING-H2 finger-type E3 ubiquitin ligases and comprises 80 members is one class of these 470 genes (Jensen et al. 1998; Serrano et al. 2006). The expression of

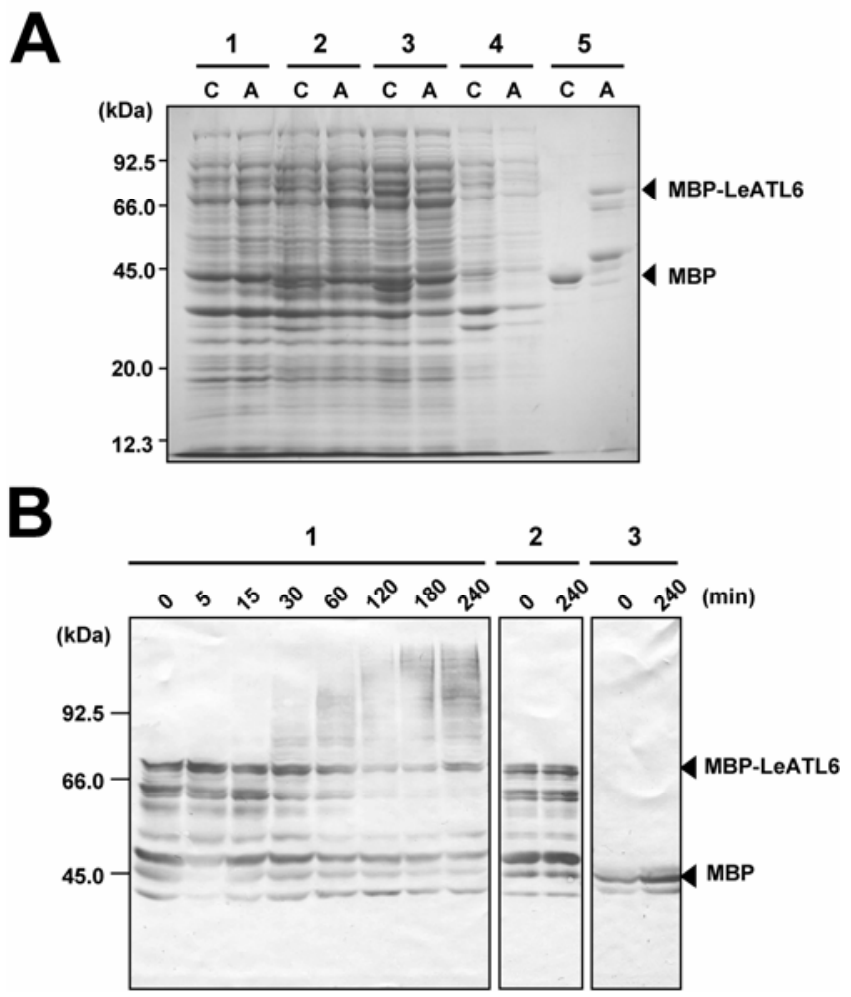

Fig. 3. Expression of the maltose-binding protein (MBP)-LeATL6 fusion protein in Escherichia coli and detection of ubiquitination activity. A, Truncated LeATL6, in which the N-terminal 89-amino-acid region was deleted, was expressed in E. coli as a fusion protein with MBP. E. coli strain BL21 containing pMAL-p2:LeATL6 in which the truncated LeATL6 cDNA was cloned downstream of MBP in the frame (A) or only pMAL-p2 as a control (C) was cultured without (1) or with (2-5) IPTG. Total protein in the cell extract (1 and 2), crude protein extract (3), and insoluble protein fraction (4) as well as MBP-LeATL6 and MBP that were purified by amylose affinity chromatography (5) were separated by $7.5 \%$ sodium dodecyl sulfate polyacrylamide gel electrophoresis. B, MBP-LeATL6 was modified when incubated with wheat germ lysate as a source of E1 and E2. Aliquots of the reaction mixture containing MBP-LeATL6, ubiquitin, ATP, and wheat germ lysate were sampled at $0,5,15,30,60,120,180$, and 240 min after incubation (1). As a control, the reaction mixture lacking wheat germ lysate (2) and containing MBP instead of MBP-LeATL6 (3) was incubated for $240 \mathrm{~min}$. These reaction mixtures were subjected to immunoblotting with the anti-MBP antibody. 
some members of the ATL gene family in response to elicitors also has been characterized in A. thaliana and Oryza sativa (Salinas-Mondragon et al. 1999; Serrano et al. 2006; Takai et al. 2001). The expression of ATL2 and ATL6 in A. thaliana was induced 15 to 30 min after treatment with chitin or cellulysin (Salinas-Mondragon et al. 1999). The EL5 gene of $O$. sativa, which shows structural similarity to the ATL genes of $A$. thaliana, also was upregulated 45 min after treatment with an
A

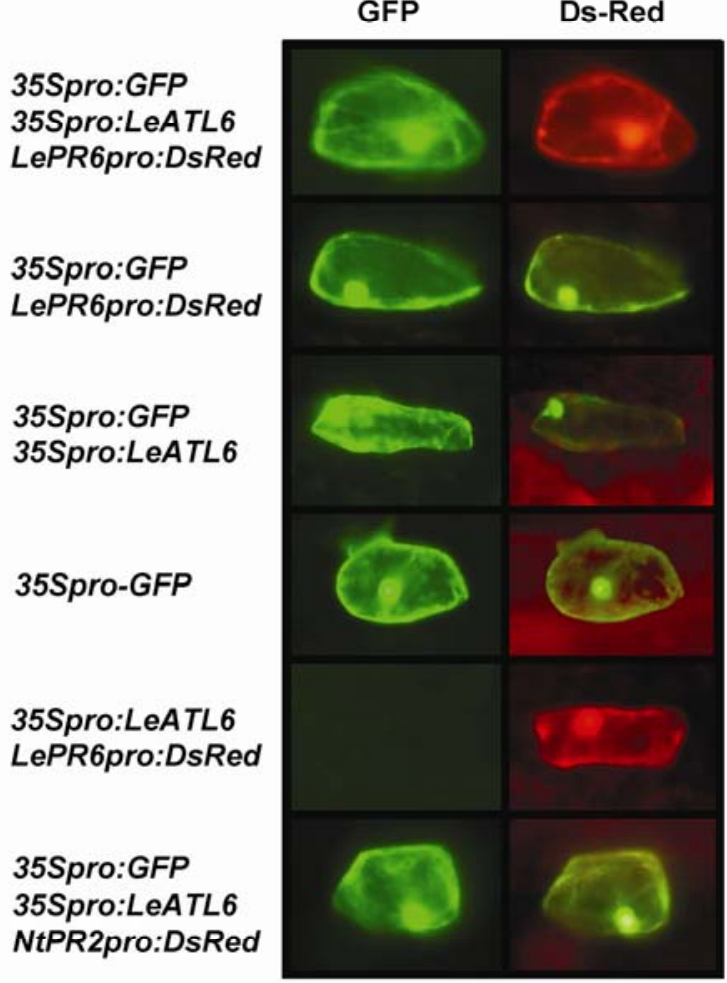

C

35Spro:GFP
35Spro:LeATL6
TPI-1pro:DsRed
35Spro:GFP
TPI-1pro:DsRed
35Spro:GFP
35Spro:LeATL6
35Spro-GFP
35Spro:LeATL6
TPI-1pro:DsRed
35Spro:GFP
35Spro:LeATL6
NtPR1pro:DsRed

35Spro:GFP 35Spro:LeATL6 TPI-1pro:DsRed

35Spro:GFP TPI-1pro:DsRed

35Spro:GFP 35Spro:LeATL6 NtPR1pro:DsRed
B

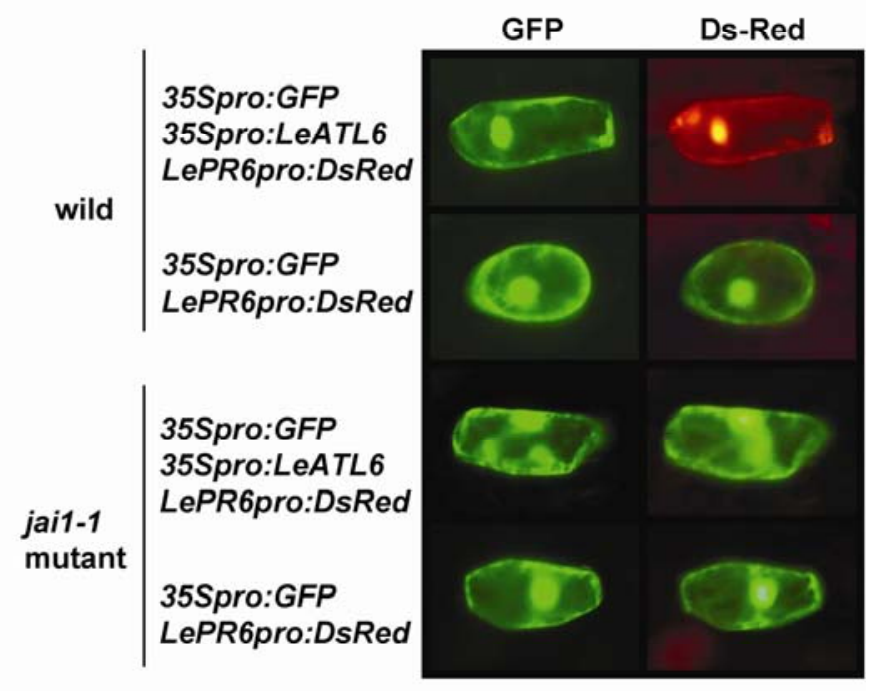

D

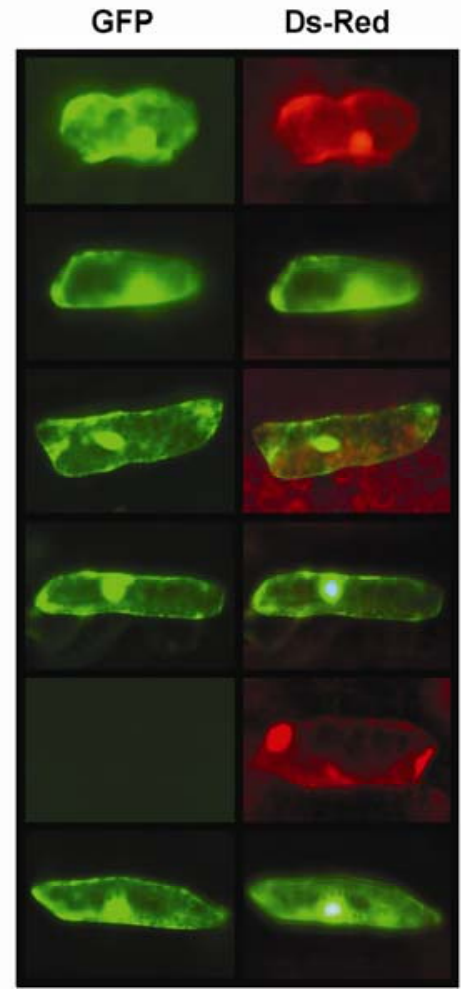

wild

35Spro:GFP

35Spro:LeATL6 TPI-1pro:DsRed

35Spro:GFP TPI-1pro:DsRed

35Spro:GFP

35Spro:LeATL6 TPI-1pro:DsRed

jai1-1

mutant

35Spro:GFP

TPI-1pro:DsRed

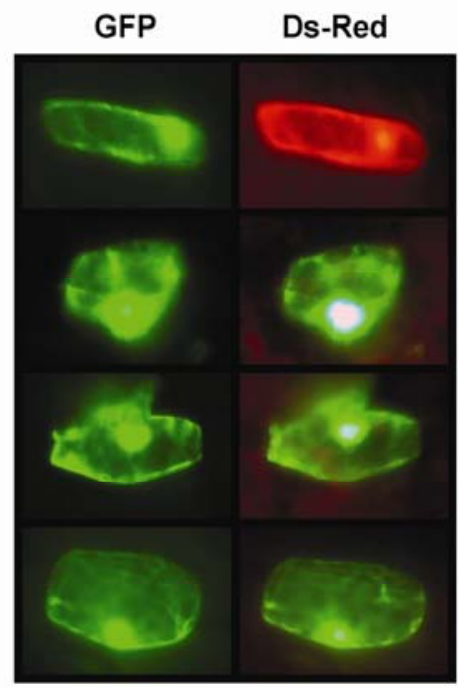


$N$-acetylchitooligosaccharide elicitor (Takai et al. 2001). In our experiments, the induction of the expression of LeATL6, an ortholog of $A T L 6$, in early response to a fungal elicitor in tomato also was demonstrated. Therefore, early elicitor induction of a member of the $A T L$ gene family and its orthologous genes encoding the RING-H2 finger protein may be a general response in monocot and dicot plant species. However, we need to study the downstream responses that are controlled by defense regulatory protein targeted by ubiquitination with RING-type E3 ubiquitin ligases encoded on some members of ATL gene family (e.g., ATL2 and ATL6).

It is well known that an elicitor induces a set of defense responses: accumulation of PR proteins, production of reactive oxygen species, ion fluxes, and phytoalexin synthesis (Boller 1995). Thus far, the relationship between the upregulation of elicitor-responsive $A T L$ genes and the activation of these defense responses was not elucidated due to limited understanding. However, our result suggested that LeATL6 expression under the control of the CaMV $35 \mathrm{~S}$ promoter activated the basic PR6 and TPI-1 promoters in wild tomato, indicating that elicitor-induced LeATL6 expression might regulate the activation of certain members of the $P R$ gene family and some other defense responses. Basic PR6 and TPI-1, encoding proteinase inhibitor II and I, respectively, generally are regulated via JAdependent signaling pathway (Glazebrook 2001; Li et al. 2004). In fact, the PR6 transcript did not accumulate in the CWP-treated jail-1 mutant tomato plants. In our previous experiment, the CWP-induced resistance in tomato appeared to activate the JA- and ethylene-dependent signaling pathways (Hase et al. 2006; Takahashi et al. 2006). Furthermore, CWPtreated wild tomato showed enhanced resistance to Ralstonia solanacearum, whereas the CWP-induced resistance was compromised in JA-insensitive jail-1 mutant tomato (S. Hase, A. Shimizu, K. Nakaho, S. Takenaka, and H. Takahashi, unpublished results). Therefore, LeATL6 probably plays an important role in the CWP-induced resistance to pathogens via JAdependent signaling pathways.

More direct evidence of the regulation of the defense response by LeATL6 may be obtained by studying transgenic tomato overexpressing LeATL6 under the control of the CaMV $35 \mathrm{~S}$ promoter. However, although we attempted to stably introduce the 35Spro:LeATL6 construct into tomato by using an Agrobacterium-mediated transformation system, all transgenic plants that overexpressed LeATL6 died during regeneration of the transformants. It has been demonstrated that yeast cells that express Arabidopsis ATL2 have a lethal phenotype (MartinezGarcia et al. 1996). Arabidopsis mutants in which the expression of the members of the $A T L$ gene family was constitutively induced showed a severely stunted phenotype (Serrano and Guzman 2004). Furthermore, the overexpression of the alfalfa $M s R H 2-1$ gene that shows the greatest homology to ATL4 induces pleiotropic effects on plant growth and development (Karlowski and Hirsch 2003). These facts suggest that it may be difficult to obtain transgenic tomato plants overex- pressing LeATL6. Therefore, in our experiment, LeATL6 was expressed transiently to analyze the relationship between the upregulation of LeATL6 and $P R$ gene expression. A weak DsRed signal was observed in some cells introduced with the PR6pro:DsRed and 35Spro:GFP constructs (Fig. 5); however, this phenomenon appears to be caused by mechanical wounding due to particle bombardment. This is because the induction of PR6 and TPI-1 gene expression by mechanical wounding has been reported frequently in tomato (Ryan 2000). On the other hand, on introducing the PR6pro:DsRed and 35Spro:GFP constructs, the number of cells that expressed DsRed in tomato cells with 35Spro:LeATL6 was threefold higher than that in tomato cells without 35Spro:LeATL6. This significant increase in the number of cells expressing DsRed by the coexpression of 35Spro:LeATL6 indicates that the transient assay method using particle bombardment is effective for detecting LeATL6regulated PR6 gene expression. The same transient assay method also was proved by detecting LeATL6-regulated TPI-1 gene expression.

The role of ubiquitin ligase E3 has been studied more extensively for its gene-for-gene resistance with respect to $A v r-R$ gene interaction (Durrant et al. 2000; Gonzalez-Lamothe et al. 2006; Kawasaki et al. 2005; Yang et al. 2006), although the association of the ubiquitin/proteasome system with plantpathogen interaction also was suggested in tobacco plants systemically infected with Tobacco mosaic virus and in cucumber seedlings treated with specific inhibitors of proteasome activity (Becker et al. 2000; Takizawa et al. 2005). P. oligandrum has been utilized as a biocontrol agent for controlling the damping-off of cress caused by P. ultimum and has been commercialized as Polygardron (Polyversum) in the Slovak Republic (Brozova 2002; Butt and Copping 2000). The glycoprotein elicitor CWP, which is present in the cell wall fraction of $P$. oligandrum, appears to play an important role in enhancing the potency of $P$. oligandrum in controlling plant diseases. This is based on the fact that the damping-off disease caused by Rhizoctonia solani AG2-2 in sugar beet, Fusarium head blight caused by Fusarium graminearum in wheat, and bacterial wilt disease caused by $R$. solanacearum in tomato were suppressed by the treatment with CWP (Hase et al. 2006; Takenaka et al. 2003). Furthermore, induction of defenserelated gene expression by CWP treatment also has been observed in sugar beet, rice, and potato (Takenaka et al. 2006) (A. Shimizu and H. Takahashi, unpublished results). CWP possesses two major proteins, POD-1 and POD-2 (Takenaka et al. 2006). POD-1 and POD-2 contain elicitin signatures and Olinked glycosylation sites which may be associated with its linkage to the cell wall of $P$. oligandrum, and it is easily released in vitro from the cell wall at high $\mathrm{CaCl}_{2}$ concentrations (Takenaka et al. 2003). The general elicitor activity and indispensable structure of POD for the microbial lifestyle suggest that CWP is recognized as an invariant PAMPs by the plant surveillance system. The finding that the induction of LeATL6 by CWP treatment regulates the expression of JA-dependent

Fig. 4. Transient DsRed expression under the control of the basic PR6 and TPI-1 promoters by overexpression of LeATL6 in the wild and jail-1 mutant tomato cells. A, A series of the combination of the 35Spro:LeATL6, LePR6pro:DsRed, NtPR2pro:DsRed, and 35Spro:GFP constructs was introduced into the epidermal cells of wild tomato leaves by the particle bombardment. B, A combination of the 35Spro:LeATL6, LePR6pro:DsRed, and 35Spro:GFP constructs and that of LePR6pro:DsRed and 35Spro:GFP were introduced into the epidermal cells of wild and jail-1 mutant tomato leaves by the particle bombardment. C, A series of the combination of the 35Spro:LeATL6, TPI-1pro:DsRed, NtPR1pro:DsRed, and 35Spro:GFP constructs was introduced into the epidermal cells of wild tomato leaves by the particle bombardment. D, A combination of the 35Spro:LeATL6, TPI-1pro:DsRed, and 35Spro:GFP constructs and that of TPI-1pro:DsRed and 35Spro:GFP were introduced into the epidermal cells of wild and jail-1 mutant tomato leaves by the particle bombardment. In both experiments, the leaves were observed $12 \mathrm{~h}$ after bombardment by using a fluorescence microscope. The GFP signal was detected using Zwiss filter no. 10 (excitation at 450 to $490 \mathrm{~nm}$ per emission at 515 to $565 \mathrm{~nm}$ ), whereas the DeRed signal was detected using Zwiss filter no. 15 (excitation at BP546 nm per emission at LP590 nm). Filter no. 15 could not exclude the GFP signal; therefore, a yellow-red-colored signal that was caused by the overlap of the fluorescence of DsRed and GFP was observed using filter no. 15 . 
basic PR-6 will provide a better understanding of the role of ubiquitin ligase E3 in PAMP-mediated defense in plants.

The MBP-LeATL6 fusion protein produced in E. coli exhibited ubiquitin ligase activity in vitro when incubated with ubiquitin, ATP, and wheat germ lysate as a source of the ubiquitinactivating enzyme (E1) and ubiquitin-conjugated enzyme (E2). Arabidopsis spp. possess two genes corresponding to E1 isoforms and approximately 45 genes corresponding to E2 or E2like proteins; however, almost 1,200 genes appear to encode E3 enzymes (Smalle and Vierstra 2004). However, certain E1 and E2 proteins that should interact with LeATL6 as E3 in vivo have not been identified. Among the three enzymes, E3 plays a major role in determining the specificity of a substrate for ubiquitination. Although the target protein for LeATL6 has not been identified, the C-terminal half of the protein belonging to the ATL family that contains a variable region appears to determine the target specificity. Therefore, the identification of E1 and E2 proteins that function with LeATL6 and the characterization of the target protein of LeATL6 will provide novel insights on the downstream signaling mechanisms of LeATL6 in PAMP-induced defense responses.

\section{MATERIALS AND METHODS}

\section{Plants and fungal cultures.}

Lycopersicon esculentum cv. Micro-Tom and its jail-1 mutant ( $\mathrm{Li}$ et al. 2004) were grown in quartz sand at $24^{\circ} \mathrm{C}$ in a growth chamber under continuous fluorescent light $(70 \mu \mathrm{mol}$ $\mathrm{m}^{-2} \mathrm{~s}^{-1}$ ) and fertilized with a thousand-fold diluted Hyponex solution (Hyponex Japan, Osaka, Japan) at 3-day intervals (Takahashi et al. 2005). The P. oligandrum (PO) isolate MMR2 was cultured in $10 \%$ V8 broth containing $0.15 \mathrm{M}$
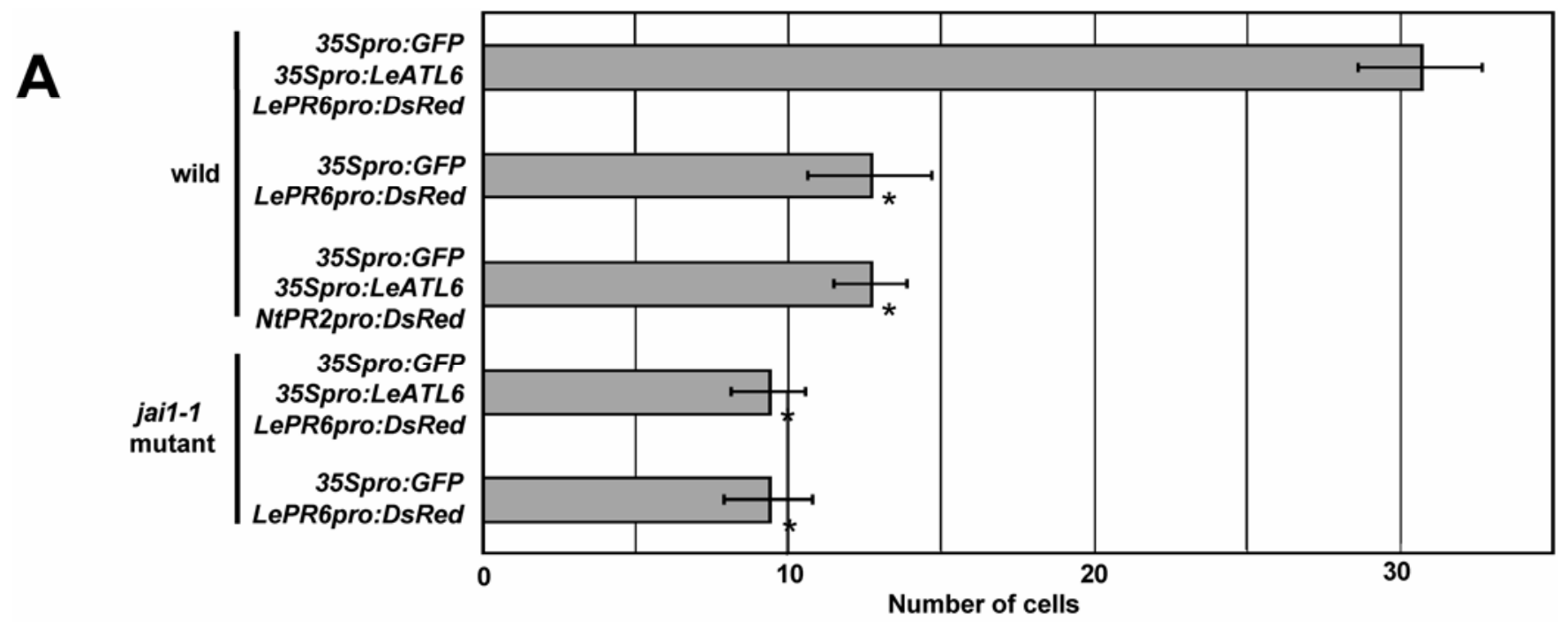

B

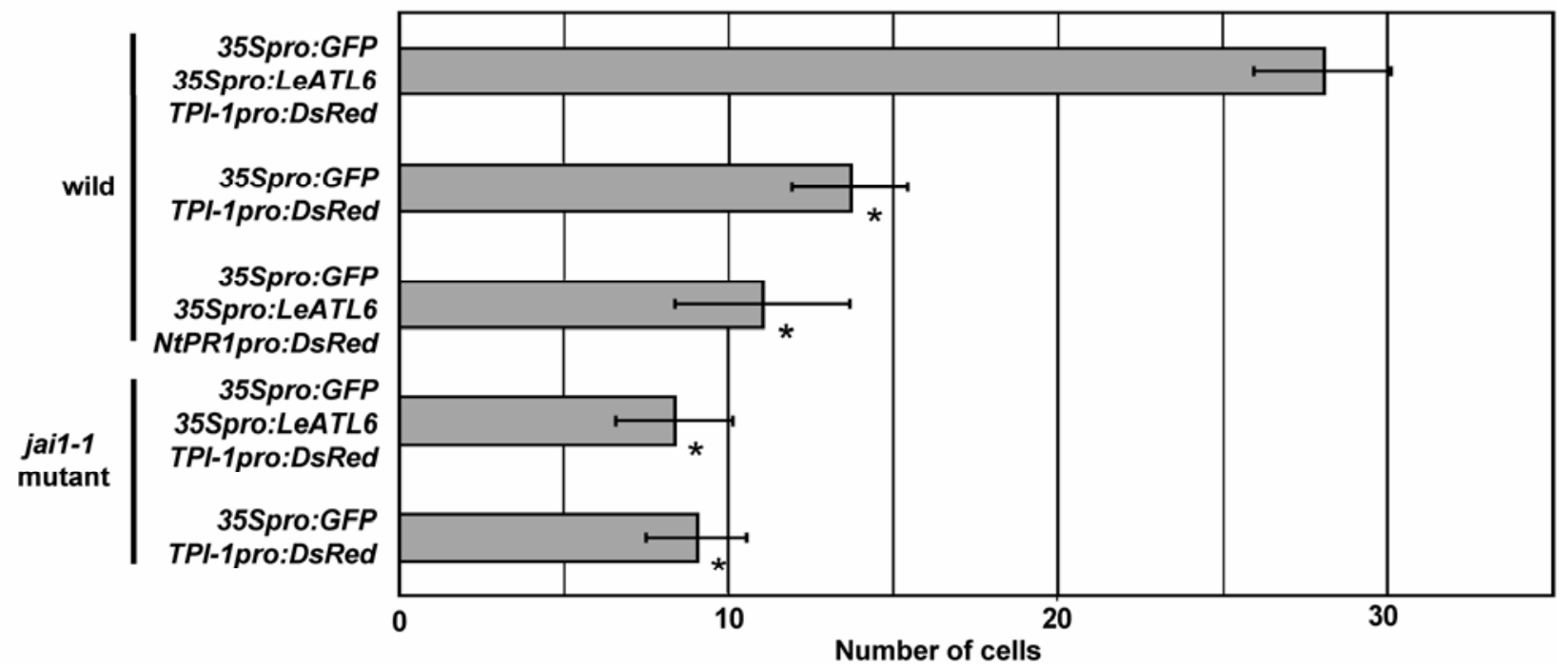

Fig. 5. Number of cells expressing the DsRed under the control of the basic PR6 and TPI-1 promoters by overexpression of LeATL6 in the wild and jail-1 mutant tomato cells. A, Number of cells expressing the DsRed fluorescence signals when a series of a combination of the 35Spro:LeATL6, LePR6pro:DsRed, NtPR2pro:DsRed, and 35Spro:GFP constructs were introduced into wild and jail-1 mutant tomato cells. The number of DsRed-expressing cells per 60 GFPexpressing cells was counted. Average number of DsRed-expressing cells in the triplicate experiments was shown. The bars indicate standard deviation (SD) for the triplicate experiments. Asterisks indicate a significant difference between number of the cells expressing the DsRed fluorescence signal in a combination of the 35Spro:LeATL6, LePR6pro:DsRed, and 35Spro:GFP constructs compared with other combinations of vector constructs according to a $t$ test $(P<$ 0.05). B, Number of cells expressing the DsRed fluorescence signals when a series of a combination of the 35Spro:LeATL6, TPI-1pro:DsRed, NtPRIpro:DsRed, and 35Spro:GFP constructs were introduced into wild and jail-1 mutant tomato cells. The number of DsRed-expressing cells per 60 GFPexpressing cells was counted. Average number of DsRed-expressing cells in the triplicate experiments was shown. The bars indicate SD for the triplicate experiments. Asterisks indicate a significant difference between number of the cells expressing the DsRed fluorescence signal in a combination of the 35Spro:LeATL6, TPI-1pro:DsRed, and 35Spro:GFP constructs compared with other combinations of vector constructs according to a $t$ test $(P<0.05)$. 
$\mathrm{CaCO}_{3}$ and $0.1 \%$ of wheat germ oil at $25^{\circ} \mathrm{C}$ for 3 weeks. The mycelial mats were collected by filtration and washed with distilled water.

\section{Treatment with the mycelial homogenate of $P$. oligandrum.}

Fourteen-day-old tomato plants were harvested carefully from the plants grown in quartz sand; care was taken to minimize damage to the root tissue by preventing injury. After rinsing the roots three times with distilled water, the roots of one plant were dipped into $1 \mathrm{ml}$ of mycelial homogenate containing $5 \times 10^{5}$ oospores and incubated at $24^{\circ} \mathrm{C}$ under continuous fluorescent light $\left(70 \mu \mathrm{mol} \mathrm{m} \mathrm{m}^{-2} \mathrm{~s}^{-1}\right)$. The mycelial homogenate was prepared as described previously (Hase et al. 2006).

\section{Cloning of ATL6 cDNA from tomato.}

Total RNA was isolated from CWP-treated tomato roots by using an RNeasy plant mini kit (Qiagen, Hilden, Germany). Five micrograms of the total RNA was reverse transcribed to synthesize first-strand cDNA by using an oligo(dT) primer and the ThermoScript reverse-transcription polymerase chain reaction (PCR) system (Invitrogen, Carlsbad, CA, U.S.A.). Using the first-strand cDNA as a template, LeATL6 cDNA was amplified by PCR. For the PCR, $1 \mu \mathrm{g}$ of the first-strand cDNA was added to $50 \mu \mathrm{l}$ of $10 \mathrm{mM}$ Tris- $\mathrm{HCl}(\mathrm{pH} 8.3)$ containing $50 \mathrm{mM}$ $\mathrm{KCl} ; 2 \mathrm{mM} \mathrm{MgCl}$; $0.2 \mathrm{mM}$ each dATP, dCTP, dGTP, and dTTP; 5 units of KOD-plus DNA polymerase (Toyobo, Kyoto, Japan); and $0.2 \mu \mathrm{M}$ of primers LeATL6-F1 (5'-CCACCAAAA GCTGCCATGG-3') and LeATL6-R1 (5'-ATTCTTTAAACCG GAGATCG-3'). PCR was performed as follows: 30 cycles at $94^{\circ} \mathrm{C}$ for $1 \mathrm{~min}, 55^{\circ} \mathrm{C}$ for $2 \mathrm{~min}$, and $73^{\circ} \mathrm{C}$ for $1 \mathrm{~min}$. The PCR product was puri $\bullet$ ed and then cloned into the EcoRV site of pBluescript SK+ (Stratagene, La Jolla, CA, U.S.A.) by the procedure described previously (Takahashi and Ehara 1993). To confirm that the DNA of interest had been cloned, the nucleotide sequence of the insert was determined by the Sanger method using the automated DNA sequencer ABI model 310A (Applied Biosystems, Foster City, CA, U.S.A.), and the resultant plasmid vector was named pBS+SK.LeATL6.

\section{Northern hybridization analysis.}

Total RNA was isolated from the roots of the tomato plants by using an RNeasy plant mini kit according to the instruction manual. Ten micrograms of total RNA was loaded in each lane of a $1.2 \%$ denaturing agarose gel. Northern hybridization was performed according to a published protocol (Sambrook and Russell 2001). To detect LeATL6 expression, cDNA was labeled with $\left[{ }^{32} \mathrm{P}\right] \mathrm{dCTP}$ by using the Megaprime DNA labeling systems (Amersham-Pharmacia, Piscataway, NJ, U.S.A.).

\section{Expression of the ATL6 protein in E. coli.}

By using PCR, we amplified the LeATL6 fragment encoding a truncated LeATL6 protein that lacked N-terminal 89 amino acids and contained a highly conserved amino acid sequencecontaining region (region III) and a RING-H2 zinc-finger domain (region IV) (Fig. 2). pBS+SK.LeATL6 served as a template and the two primers LeATL6-ERI-F1 (5'-GGAATTCGG ACTTGAAGATTCCGTCATCG-3') and LeATL6-ERI-R1 (5'GGAATTCATTCTTTAAACCGGAGATCG-3') were used (the EcoRI sites are underlined). The PCR conditions were similar to those described above. The PCR product was purified, digested with EcoRI, and then cloned into the EcoRI site of pMAL-p2X (New England BioLabs, Beverly, MA, U.S.A.). The resultant plasmid was designated pMAL-p2X:LeATL6 $\Delta N$. In order to avoid the synthesis of a fusion protein of MBP and a partial fragment of lacZ $\alpha$ located downstream of MBP in the pMAL-p2X frame in E. coli, EcoRI-digested pMAL-p2X DNA was blunted by treatment with T4 DNA polymerase and then religated, thereby causing a shift in the open reading frame of lacZ $\alpha$. pMAL-p2X:LeATL6 $\Delta N$ and the obtained pMAL-p2 (control) were transformed into E. coli strain BL21. IPTG-inducible production of the recombinant protein and its purification by amylose affinity chromatography were performed according to the manufacturer's instructions.

\section{Ubiquitin ligase activity assay.}

The in vitro ubiquitination experiment was performed as described by Takai and associates (2002). The reaction mixture was incubated at $30^{\circ} \mathrm{C}$ for $0,5,15,30,60,120,180$, and 240 $\mathrm{min}$, and the reaction was terminated by the addition of an equal volume of SDS-PAGE buffer (Laemmli 1970). After boiling for $5 \mathrm{~min}$, the reaction mixtures were loaded on a $7.5 \%$ SDS-PAGE gel and electrophorized. MBP-LeATL6 was detected immunologically using the anti-MBP antibody (New England BioLabs).

\section{Transient assay of the activity of the basic $P R 6$ and TPI-I promoters and the acidic $P R 1$ and $P R 2$ promoters under coexpression of $\mathrm{LeATLG}$ in tomato cells.}

The promoter fragments of tomato basic PR6 encoding proteinase inhibitor II (Zhang et al. 2004), tomato basic TPI-I encoding proteinase inhibitor I (TPI-1) (Lee et al. 1986), tobacco acidic $P R 2$ encoding $\beta$-1,3-glucanase (Hennig et al. 1993), and tobacco acidic PRI (Grüner and Pfitzner 1994) were amplified by PCR from the genomic DNA of tomato and tobacco. The template DNA for PCR was isolated using the cetyltrimethylammonium bromide method (Murray and Thompson 1980). One microgram of genomic DNA was added to $50 \mu \mathrm{l}$ of $10 \mathrm{mM}$ Tris- $\mathrm{HCl}$ (pH 8.3) containing $50 \mathrm{mM} \mathrm{KCl} ; 2 \mathrm{mM}$ $\mathrm{MgCl}_{2} ; 0.2 \mathrm{mM}$ each dATP, dCTP, dGTP, and dTTP; 5 units of KOD-plus DNA polymerase (Toyobo); and $0.2 \mu \mathrm{M}$ of the primers LePR6b.pro-F1 (5'-CCCAAGCTTGGGATTTTAATA ATTGTATAACG-3', in which the HindIII site has been underlined) and LePR6b.pro-R1 (5'-CATGCCATGGTGGATAATT GATTAC-3', in which the NcoI site has been underlined) for basic PR6, TPI-1pro-F1 (5'-CCCAAGCTTGAATTCACTTCA AAACATAA-3', in which the HindIII site has been underlined) and TPI-1pro-R1 (5'-CATGCCATGGTGTTTTAGTTG TAAAGAGT- $3^{\prime}$, in which the $N c o$ I site has been underlined) for basic TPI-1, the primers NtPR2a.pro-F1 (5'-CCCAAGCTT GGGGAATTCTG-AACTTAGTTATG-3', in which the HindIIIdigestion site has been underlined) and NtPR2a.pro-R1 (5'CATGCCATGGCATGAGCTAAAATGGAAATGAGAG-3', in which the NcoI site has been underlined) for acidic $P R 2$, or NtPR1apro-F1 (5'-CCCAAGCTTGATCGTAGCACATAAAC GTT-3', in which the HindIII site has been underlined) and NtPR1apro-R1 (5'-CATGCCATGGCTATAGGAGAAATGTT GTA-3', in which the $N c o$ I site has been underlined) for acidic $P R-1$. The PCR conditions were identified to those described earlier. The resultant DNA fragment was puri•ed, digested with HindIII and NcoI, and then cloned between the HindIII and NcoI sites of Impact vector 1.1 (Plant Research International B. V., Wageningen, The Netherlands). The resultant plasmid constructs were designated pLePR6pro:rbcsT, pTPI1 pro:rbcsT, pNtPR2pro:rbcsT, and pNtPR1pro:rbcsT, respectively. In these constructs, the rbcs terminator fragment was located downstream of the promoters. To monitor the promoter activity, the BamHI- and NotI-digested DsRed fragment that was amplified from pDsRed2 (Clontech-TAKARA, Kyoto, Japan) by PCR using the two primers DsRed-F1 (5'-ACTCTA GAGGATCCCCGGGTACCGG-3', in which the BamHI site has been underlined) and DsRed-R1 (5'-TAAAGCGGCCGCC AGGACAGGTGGTGGCG-3', in which the NotI site has been underlined), by following the abovementioned procedure, was cloned between the PR6, TPI-1, PR2, or PRI promoter and the 
rbcs terminator of pLePR6pro:rbcsT, pTPI-1pro:rbcsT, pNtPR2pro:rbcsT, and pNtPR1pro:rbcsT. The nucleotide sequence of the insert was determined, and the resultant plasmid vector constructs were named LePR6pro:DsRed, pTPI-1pro: DsRed, pNtPR2pro:DsRed, and pNtPRIpro:DsRed, respectively.

To develop a vector construct for the overexpression of LeATL6 in tomato cells, the LeATL6 fragment digested from pBS+SK.LeATL6 was cloned between the CaMV 35S promoter and the NOS terminator of p35S50KP-GFP (Satoh et al. 2000) by substituting it for the BamHI- and SacI-digested 50KP-GFP fragment in $\mathrm{p} 35 \mathrm{~S} 50 \mathrm{KP}-\mathrm{GFP}$. The resultant plasmid construct was named 35Spro:LeATL6. The 35Spro:GFP construct was generated by the deletion of the BamHI- and SacII-digested 50KP fragment from $\mathrm{p} 35 \mathrm{~S} 50 \mathrm{KP}-\mathrm{GFP}$.

To detect the LeATL6-dependent activation of the basic $P R 6$, basic $T P I-1$, acidic $P R 2$, and acidic $P R 1$ promoters, a series of a combination of the 35Spro:LeATL6 and LePR6pro:DsRed, pTPI-1pro:DsRed, pNtPR2pro:DsRed, or pNtPRlpro:DsRed constructs was introduced into the epidermal cells of tomato leaves by particle bombardment (PDS1000/He particle delivery system; Bio-Rad, Hercules, CA, U.S.A.) with the 35Spro:GFP construct which was coexpressed for the identification of the bombarded cells. The leaves then were incubated at $25^{\circ} \mathrm{C}$ for $12 \mathrm{~h}$ under continuous fluorescent light $\left(70 \mu \mathrm{mol} \mathrm{m} \mathrm{m}^{-2} \mathrm{~s}^{-1}\right)$. Under a fluorescence microscope (Zwiss Axioplan 1, Oberkochen, Germany), GFP fluorescence was detected using Zwiss filter no. 10 (excitation at 450 to 490 $\mathrm{nm}$ per emission at 515 to $565 \mathrm{~nm}$ ) and DsRed fluorescence, using filter no. 15 (excitation at BP546 nm per emission at LP590 nm). The degree of LeATL6-dependent activation of the basic $P R 6$, basic TPI-1, acidic $P R-2$, and acidic $P R 1$ promoters was determined in wild and jail-1 mutant tomato by counting the number of DsRed-expressing cells per 60 GFPexpressing cells.

\section{ACKNOWLEDGMENTS}

This work was supported by a grant obtained from the "Research and Development Program for New Bio-industry Initiatives" at the Bio-oriented Technology Research Advancement Institute, Japan. We thank G. A. Howe at Michigan State University, U.S.A., for kindly providing the jail-1 mutant tomato seed.

\section{LITERATURE CITED}

Austin, M. J., Muskett, P., Kahn, K., Feys, B. J., Jones, J. D. G., and Parker, J. E. 2002. Regulatory role of SGT1 in early $R$ gene-mediated plant defenses. Science 295:2077-2080.

Azevedo, C., Sadanandom, A., Kitagawa, K., Freialdenhoven, A., Shirasu, K., and Schulze-Lefert, P. 2002. The RAR1 interactor SGT1, an essential component of $R$ gene-triggered disease resistance. Science 295:2073-2076.

Becker, J., Kempf, R., Jeblick, W., and Kauss, H. 2000. Induction of competence for elicitation of defense responses in cucumber hypocotyls requires proteasome activity. Plant J. 21:311-316.

Boller, T. 1995. Chemoperception of microbial signals in plant cells. Annu. Rev. Plant Physiol. Plant Mol. Biol. 46:189-214.

Borden, K. L. B., and Freemont, P. S. 1996. The RING finger domain: A recent example of a sequence-structure family. Curr. Opin. Struct. Biol. 6:395-401.

Brozova, J. 2002. Exploitation of the mycoparasitic fungus Pythium oligandrum in plant protection. Plant Prot. Sci. 38:29-35.

Butt, T. M., and Copping, L. G. 2000. Fungal biological control agents. Pestic. Outlook 11:186-191.

Devoto, A., Muskett, P. R., and Shirasu, K. 2003. Role of ubiquitination in the regulation of plant defence against pathogens. Curr. Opin. Plant Biol. 6:307-311.

Durrant, W. E., Rowland, O., Piedras, P., Hammond-Kosack, K. E., and Jones, J. D. G. 2000. cDNA-AFLP reveals a striking overlap in racespecific resistance and wound response gene expression profiles. Plant Cell 12:963-977.

Ellis, C., Turner, J. G., and Devoto, A. 2002. Protein complexes mediate signalling in plant responses to hormones, light, sucrose and pathogens. Plant Mol. Biol. 50:971-980.

Glazebrook, J. 2001. Genes controlling expression of defense responses in Arabidopsis-2001 status. Curr. Opin. Plant Biol. 4:301-308.

Gonzalez-Lamothe, R., Tsitsigiannis, D. I., Ludwig, A. A., Panicot, M., Shirasu, K., and Jones, J. D. G. 2006. The U-box protein CMPG1 is required for efficient activation of defense mechanisms triggered by multiple resistance genes in tobacco and tomato. Plant Cell 18:1067-1083.

Grüner, R., and Pfitzner, U. M. 1994. The upstream region of the gene for the pathogenesis-related protein 1a from tobacco responds to environmental as well as to developmental signals in transgenic plants. Eur. J. Biochem. 220:247-255.

Hammond-Kosack, K. E., and Parker, J. E. 2003. Deciphering plant-pathogen communication: Fresh perspectives for molecular resistance breeding. Curr. Opin. Biotechnol. 14:177-193.

Hase, S., Shimizu, A., Nakaho, K., Takenaka, S., and Takahashi, H. 2006. Induction of transient ethylene and reduction in severity of tomato bacterial wilt by Pythium oligandrum. Plant Pathol. 55:537-543.

Hennig, J., Dewey, R. E., Cutt, J. R., and Klessig, D. F. 1993. Pathogen, salicylic acid and developmental dependent expression of a $\beta-1,3$-glucabase/GUS gene fusion in transgenic tobacco plants. Plant J. 4:481-493.

Hershko, A., and Ciechanover, A. 1998. The ubiquitin system. Annu. Rev. Genet. 67:425-479.

Jensen, R. B., Jensen, K. L., Jespersen, H. M., and Skriver, K. 1998. Widespread occurrence of a highly conserved RING-H2 zinc finger motif in the model plant Arabidopsis thaliana. FEBS (Fed. Eur. Biochem. Soc.) Lett. 436:283-287.

Kamoun, S., Lindqvist, H., and Govers, F. 1997. A novel class of elicitinlike genes from Phytophthora infestans. Mol. Plant-Microbe Interact. 10:1028-1030.

Karlowski, W. M., and Hirsch, A. M. 2003. The over-expression of an alfalfa RING-H2 gene induces pleiotropic effects on plant growth and development. Plant Mol. Biol. 52:121-133.

Kawasaki, T., Nam, J., Boyes, D. C., Holt, B. F, III., Hubert, D. A., Wiig, A., and Dangl, J. L. 2005. A duplicated pair of Arabidopsis RING-finger E3 ligases contribute to the RPM1- and RPS2-mediated hypersensitive response. Plant J. 44:258-270.

Laemmli, U. K. 1970. Cleavage of structural proteins during the assembly of the head of bacteriophage T4. Nature 227:680-685.

Lee, J. S., Brown, W. E., Graham, J. S., Pearce, G., Fox, E. A., Dreher, T. W., Ahern, K. G., Pearson, G. D., and Ryan, C. A. 1986. Molecular characterization and phylogenetic studies of a wound-inducible proteinase inhibitor I gene in Lycopersicon species. Proc. Natl. Acad. Sci. U.S.A. 83:7277-7281.

Li, L., Zhao, Y., McCaig, B. C., Wingerd, B. A., Wang, J., Whalon, M. E., Pickersky, E., and Howe, G. A. 2004. The tomato homolog of CORONATINE-INSENSITIVE1 is required for the maternal control of seed maturation, jasmonate-signaled defense responses, and glandular trichome development. Plant Cell 16:126-143.

Liu, Y., Schiff, M., Serino, G., Deng, X. W., and Dinesh-Kumar, S. P. 2002. Role of SCF ubiquitin-ligase and the COP9 signalosome in the $N$ gene-mediated resistance response to Tobacco mosaic virus. Plant Cell 14:1483-1496.

Martínez-García, M., Garcidueñas-Piña, C., and Guzmán, P. 1996. Gene isolation in Arabidopsis thaliana by conditional overexpression of cDNAs toxic to Saccharomyces cerevisiae: Identification of a novel early response zinc-finger gene. Mol. Gen. Genet. 252:587-596.

Murray, M. G., and Thompson, W. F. 1980. Rapid isolation of high molecular weight plant DNA. Nucleic Acids Res. 8:4321-4325.

Muskett, P. R., Kahn, K., Austin, M. J., Moisan, L. J., Sadanandom, A., Shirasu, K., Jones, J. D. G., and Parker, J. E. 2002. Arabidopsis RAR1 exerts rate-limiting control of $R$-gene-mediated defenses against multiple pathogens. Plant Cell 14:979-992.

Nürnberger, T., Brunner, F., Kemmerling, B., and Piater, L. 2004. Innate immunity in plants and animals: Striking similarities and obvious differences. Immunol. Rev. 198:249-266.

Panabieres, F., Ponchet, M., Allasia, V., Cardin, L., and Ricci, P. 1997. Characterization of border species among Pythiaceae: Several Pythium isolates produce elicitins, typical proteins from Phytophthora spp. Mycol. Res. 101:1459-1468.

Peart, J. R., Lu, R., Sadanandom, A., Malcuit, I., Moffett, P., Brice, D. C., Schauser, L., Jaggard, D. A. W., Xiao, S., Coleman, M. J., Dow, M., Jones, J. D. G., Shirasu, K., and Baulcombe, D. C. 2002. Ubiquitin ligase-associated protein SGT1 is required for host and nonhost disease resistance in plants. Proc. Natl. Acad. Sci. U.S.A. 99:10865-10869.

Picard, K., Ponchet, M., Blein, J. P., Rey, P., Tirilly, Y., and Benhamou, N. 2000. Oligandrin. A proteinaceous molecule produced by the mycoparasite Pythium oligandrium induces resistance to Phytophthora parasitica infection in tomato plants. Plant Physiol. 124:379-395.

Ponchet, M., Panabieres, F., Milat, M.-L., Mikes, V., Montillet, J.-L., Suty, 
L., Triantaphylides, C., Tirilly, Y., and Blein, J.-P. 1999. Are elicitins cryptograms in plant-Oomycete communications? CMLS Cell. Mol. Life Sci. 56:1020-1047.

Ryan, C. A. 2000. The systemin signaling pathway: Differential activation of plant defensive genes. Biochim. Biophys. Acta 1477:112-121.

Salinas-Mondragon, R. E., Garciduenas-Pina, C., and Guzman, P. 1999. Early elicitor induction in members of a novel multigene family coding for highly related RING-H2 proteins in Arabidopsis thaliana. Plant Mol. Biol. 40:579-590.

Sambrook, J., and Russell, D. W. 2001. Molecular Cloning: A Laboratory Manual. 3rd ed. Cold Spring Harbor Laboratory, Cold Spring Harbor, NY, U.S.A.

Satoh, H., Matsuda, H., Kawamura, T., Isogai, M., Yoshikawa, N., and Takahashi, T. 2000. Intracellular distribution, cell-to-cell trafficking and tubule-inducing activity of the $50 \mathrm{kDa}$ movement protein of Apple chlorotic leaf spot virus fused to green fluorescent protein. J. Gen. Virol. 81:2085-2093.

Saurin, A. J., Borden, K. L. B., Boddy, M. N., and Freemont, P. S. 1996. Does this have a familiar RING? Trends Biochem. Sci. 21:208-214.

Serrano, M., and Guzman, P. 2004. Isolation and gene expression analysis of Arabidopsis thaliana mutants with constitutive expression of ATL2, an early elicitor-response RING-H2 zinc-finger gene. Genetics 167:919-929.

Serrano, M., Parra, S., Alcaraz, L. D., and Guzman, P. 2006. The ATL gene family from Arabidopsis thaliana and Oryza sativa comprises a large number of putative ubiquitin ligases of the RING-H2 type. J. Mol. Evol. 62:434-445

Shirasu, K., Lahaye, T., Tan, M.-W., Zhou, F., Azevedo, C., and SchulzeLefert, P. 1999. A novel class of eukaryotic zinc-binding proteins is required for disease resistance signaling in barley and development in $C$. elegans. Cell 99:355-366.

Smalle, J., and Vierstra, R. D. 2004. The ubiquitin 26S proteasome proteolytic pathway. Annu. Rev. Plant Biol. 55:555-590.

Takahashi, H., and Ehara, Y. 1993. Severe chlorotic spot symptoms in cucumber mosaic virus strain Y-infected tobaccos are induced by a combination of the virus coat protein gene and two host recessive genes. Mol. Plant-Microbe Interact. 6:182-189.

Takahashi, H., Shimizu, A., Arie, T., Rosmalawati, S., Fukushima, S., Kikuchi, M., Hikichi, Y., Kanda, A., Takahashi, A., Kiba, A., Ohnishi, K., Ichinose, Y., Taguchi, F., Yasuda, C., Kodama, M., Egusa, M., Masuta, C., Sawada, H., Shibata, D., Hori, K., and Watanabe, Y. 2005. Catalog of Micro-Tom tomato responses to common fungal, bacterial and viral pathogens. J. Gen. Plant Pathol. 71:8-22.

Takahashi, H., Ishihara, T., Hase, S., Chiba, A., Nakaho, K., Arie, T., Teraoka, T., Iwata, M., Tugane, T., Shibata, D., and Takenaka, S. 2006. Beta-cyanoalanine synthase as a molecular marker for induced resistance by fungal glycoprotein elicitor and commercial plant activators. Phytopathology 96:908-916.

Takai, R., Hasegawa, K., Kaku, H., Shibuya, N., and Minami, E. 2001. Isolation and analysis of expression mechanisms of a rice gene, EL5, which shows structural similarity to ATL family from Arabidopsis, in response to $N$-acetylchitooligosaccharide elicitor. Plant Sci. 160:577-583.

Takai, R., Matsuda, N., Nakano, A., Hasegawa, K., Akimoto, C., Shibuya, N., and Minami, E. 2002. EL5, a rice $N$-acetylchitooligosaccharide elicitor-responsive RING-H2 finger protein, is a ubiquitin ligase which functions in vitro in co-operation with an elicitor-responsive ubiquitinconjugating enzyme, OsUBC5b. Plant J. 30:447-455.

Takenaka, S., and Kawasaki, S. 1994. Characterization of alanine-rich, hydroxyproline-containing cell wall proteins and their application for identifying Pythium species. Physiol. Mol. Plant Pathol. 45:249-261.

Takenaka, S., Nishio, Z., and Nakamura, Y. 2003. Induction of defense reactions in sugar beet and wheat by treatment with cell wall protein fractions from the mycoparasite Pythium oligandrum. Phytopathology 93:1228-1232.

Takenaka, S., Nakamura, Y., Kono, T., Sekiguchi, H., Masunaka, A., and Takahashi, H. 2006. Novel elicitin-like proteins isolated from cell wall of the biocontrol agent Pythium oligandrum induce defense-related genes in sugar beet. Mol. Plant Pathol. 7:325-339.

Takizawa, M., Goto, A., and Watanabe, Y. 2005. The tobacco ubiquitin-activating enzymes $N t E 1 A$ and $N t E 1 B$ are induced by tobacco mosaic virus, wounding and stress hormones. Mol. Cell 19:228-231.

Tor, M., Gordon, P., Cuzick, A., Eulgem, T., Sinapidou, E., Mert-Turk, F., Can, C., Dangl, J. L., and Holub, E. B. 2002. Arabidopsis SGT1b is required for defense signalling conferred by several downy mildew resistance genes. Plant Cell 14:993-1003.

Tornero, P., Merritt, P., Sadanandom, A., Shirasu, K., Innes, R. W., and Dangl, J. L. 2002. RAR1 and NDR1 contribute quantitatively to disease resistance in Arabidopsis, and their relative contributions are dependent on the $R$ gene assayed. Plant Cell 14:1005-1015.

Tyler, B. M. 2002. Molecular basis of recognition between Phytophthora pathogens and their hosts. Annu. Rev. Phytopathol. 40:137-167.

Vierstra, R. D. 2003. The ubiquitin/26S proteasome pathway, the complex last chapter in the life of many plant proteins. Trends Plant Sci. 8:135142.

Weissman, A. M. 2001. Themes and variations on ubiquitylation. Nat. Rev. Mol. Cell Biol. 2:169-178.

Yang, C.-W., Gonzalez-Lamothe, R., Ewan, R. A., Rowland, O., Yoshioka, H., Shenton, M., Ye, H., O’Donnell, E., Jones, J. D. G., and Sadanandom, A. 2006. The E3 ubiquitin ligase activity of Arabidopsis PLANT UBOX17 and its functional tobacco homolog ACRE276 are required for cell death and defense. Plant Cell 18:1084-1098.

Zhang, H.-Y., Xie, X.-Z., Xu, Y.-Z., and Wu, N.-H. 2004. Isolation and functional assessment of a tomato proteinase inhibitor II gene. Plant Physiol. Biochem. 42:437-444.

\section{AUTHOR-RECOMMENDED INTERNET RESOURCE}

The Institute for Genomic Research (TIGR) tomato genome database: www.tigr.org/tigr-scripts/tgi/T_index.cgi?species=tomato 